\title{
THE DEVELOPMENT OF ANIMATION-BASED LEARNING MEDIA USING CONSTRUCT 2 ON LOGIC MATERIAL
}

\author{
Fadila Meina Luppy¹, *Rahmad Bustanul Anwar ${ }^{2}$, Nego Linuhung ${ }^{3}$, Rina \\ Agustina $^{4}$, Dwi Rahmawati ${ }^{5}$ \\ 1,2,3,4,5 Universitas Muhammadiyah Metro

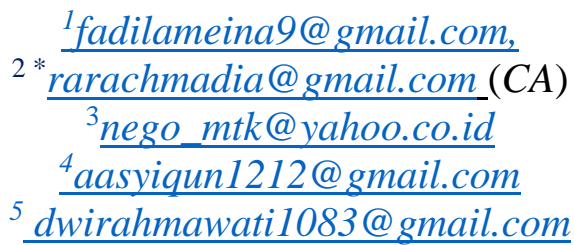

\begin{abstract}
Abstrak
Tujuan penelitian pengembangan ini adalah menghasilkan produk berupa media pembelajarn berbasis animasi menggunakan construct 2 yang "layak" digunakan sebagai media pembelajaran untuk peserta didik di SMA Negeri 1 Purbolinggo dan menghasilkan produk yang "praktis" digunakan sebagai media pembelajaran untuk peserta didik di SMA Negeri 1 Purbolinggo. Model pengembangan yang digunakan sebagai dasar penelitian ini adalah model 4D yang terdiri dari 4 tahap yaitu Define, Design, Development, Disseminate. Instrument pengumpulan data pada pengembangan ini berupa angket validasi ahli dan angket kepraktisan produk. Hasil pengembangan produk berupa media pembelajaran animasi diperoleh analisis materi $89 \%$ yang masuk dalam kategori "sangat layak" dan analisis ahli media $90 \%$ yang masuk dalam kategori "sangat layak" untuk digunakan pada saat uji coba. Selanjutnya uji coba kelompok kecil dilakukan oleh 10 peserta didik diperoleh $90 \%$ yang masuk dalam kategori "sangat praktis" digunakan pada proses pembelajaran. Berdasarkan kriteria yang telah ditetapkan media pembelajaran berbasis animasi pada materi logika yang dikembangkan memenuhi kriteria layak dan praktis.
\end{abstract}

Kata kunci: Pengembangan, media pembelajaran, berbasis animasi, Construct $2, \operatorname{logika}$.

\begin{abstract}
The purpose of this development research is to produce a product in the form of an animation-based learning media using construct 2 that is "feasible" to bw used as learning medium for students in SMA Negesi 1 Purbolinggo and to produce pruducts that are "practical" used as a learning medium for students at SMA Negeri 1 Purbolinggo. The development model used as the basid of this research is the 4D model which consists of 4 stages, namely Define, Design, Development, Disseminate. Data collection instruments in this development were expert validation questionnaire and product practicality questionnaire. The results of product development in the form of instructional media animation obtained $89 \%$ of material analysis included in the "very feasible" category and $90 \%$ of media expert analysis included in the "very feasible" category for use at the time of the trial. Furthermore, small group trials conducted by ten students obtained $90 \%$ which fall into the "very practical" ctegory used in the learning process. Based learning media on logic material that is developed it meets the feasible and practical criteria.
\end{abstract}

Keywords: development, learning media, animation-based, construct 2, logic 
Citation: Luppy, F. M., Anwar, R. B., Linuhung, N., Agustina, R., Rahmawati, D. 2019. The Development of Animation-Based Learning Media Using Construct 2 On Logic $\begin{array}{llll}\text { Material. } \quad \text { Matematika dan Pembelajaran, } & \text { 13-21. }\end{array}$ DOI: http://dx.doi.org/10.33477/mp.v6i2

\section{INTRODUCTION}

The teacher as the main actor in the learning process in the classroom should develop their potential in order to improve the quality of learning. The success of educators in delivering material is highly dependent on the smooth communication interaction between the teacher and the students. In order to facilitate this interaction media is needed as an intermediary, in addition to media in the teaching and learning process also required the existence of learning technology. Learning media can create interactive, innovative, creative, and fun learning in fostering a learning situation that is comfortable and interesting for students. Learning media that can be used include visual aids such as pictures, models, objects, and others that can provide experience, learning motivation and, enhance students' absorption ability in learning.

Until now, science and technology are increasingly developing, many technologies that can be used as a tool that is used as a source of learning for many people, especially macromedia technology. The benefits are enormous for users of these tools or media. Therefore teachers are required to use learning media in the learning process. Through learning media, teachers can provide educational services without having to deal directly with students while students can obtain information in a broad scope and a variety of sources through the use of various media, one of which is technology such as computers, smartphones, or laptops. Furthermore According to Barus \& Suratno (2015: 17), learning media are all aids or objects used in teaching and learning activities with a view to conveying learning messages (information) from the source (teacher) to the recipients of students' messages.

Based on observations made at SMA Negeri 1 Purbolinggo showed that SMA Negeri 1 Purbolingo in learning had used media such as Powerpoint but still with a monotonous appearance. In addition, the school already has adequate learning 
support facilities such as LCDs, Computers and Wi-Fi but there is still a lack of use of innovative and varied media. This causes a decrease in students' interest to learn or pay attention to the teacher when explaining the material during learning, especially mathematics learning.

To increase students' interest in the learning process, teachers can develop media that are appropriate to the needs of students. One of them is developing instructional media in the form of animated media using construct 2. Developers of this instructional learning media in the form of instructional media applications where the application can be operated by students directly. The media is certainly expected to increase the interest and motivation of students in learning logic taught to XI grade students of SMA Negeri 1 Purbolinggo. Jalinus \& Ambivar (2016: 4) revealed that the effectiveness of the teaching and learning process (learning) is strongly influenced by factors of the methods and learning media used.

Based on Shodikin's research (2017) related to the development of animation learning media using construct 2 shows that the media can influence the interests and motivation of students during learning. Shodikin's research (2017) is still limited to integral material. For this reason it needs to be developed further for other material.

Referring to the existing problems, researchers assume that animation media can make the learning process more effective so that students better understand the material of logic and further enhance the interests and motivation of students. This assumption requires proof through a series of systematic research activities. So that the core problem of this research development is the development of a valid and practical animation-based learning media. This animation learning media has an attractive design display. Both in terms of color and writing and collaborated with the sound of music so that students will not be bored using the media. This media can be used when learning at school or at home. 


\section{METHOD}

The development model used in this research development is the 4-D model (Define, Design, Development, Disseminate). The stages of developing the 4-D model adapted from Sutarti \& Edi (2017: 13) are as follows:

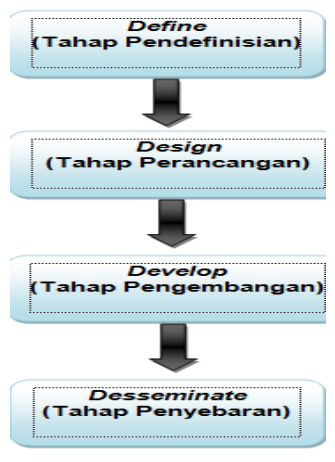

Figure 1. 4-D model stages

The data in this development research are qualitative data and quantitative data. Quantitative data was obtained from the results of comments / suggestions from questionnaires that were assessed by experts namely material experts and media experts for product validation and the results were used for improvement. Quantitative data were obtained from the scoring results from a questionnaire in the form of a description of the percentage of validity by the material experts and the practicality of the product by the students. Data collection instruments used in this study were product validation questionnaire sheets by experts and product practicality questionnaire sheets by students. The analysis technique of this research development is validation of product and material validation analysis and practicality analysis of students. The following table relates to validity and eligibility criteria

Table 1. Validity Criteria of a Product

\begin{tabular}{ccc}
\hline Value & Categories & $\boldsymbol{\%}$ \\
\hline 5 & Very decent & $80<N \leq 100$ \\
\hline 4 & Worthy & $60<N \leq 80$ \\
\hline 3 & Decent enough & $40<N \leq 60$ \\
\hline 2 & Inadequate & $20<N \leq 40$ \\
\hline 1 & Very Inadequate & $0<N \leq 20$ \\
\hline
\end{tabular}


Adaptation Riduwan dan Akdon (2013)

If the results obtained are more than $60 \%$ then the product is said to be feasible so that it is valid and can be tested. According to Iis \& Totok (2017: 209), to determine whether each item is valid or not before being used for trials, it must conduct validation for each validator, then the data is calculated with the formulas on the calculation scale used by the developer. If the scores obtained meet the eligibility criteria, then the product is declared valid for trial and suitable for use during learning.

Table 2. Practicality Criteria of a Product

\begin{tabular}{ccc}
\hline Value & Categories & $\boldsymbol{\%}$ \\
\hline 5 & Very practical & $80<N \leq 100$ \\
\hline 4 & Practical & $60<N \leq 80$ \\
\hline 3 & Practical enough & $40<N \leq 60$ \\
\hline 2 & Not Practical & $20<N \leq 40$ \\
\hline 1 & Very Not Practical & $0<N \leq 20$ \\
\hline
\end{tabular}

Adaptation Riduwan dan Akdon (2013)

If the results obtained are more than $60 \%$ then the product can be said to be practical. According to Nieveen (2007: 187), aspects of practicality are met if experts and practitioners (teachers and students) state that what is developed can be applied and supported by facts that show that what is developed can be applied.

\section{RESULT AND DISCUSSION}

The development of animation-based learning media on high school class XI logic material is presented in the following figure: 


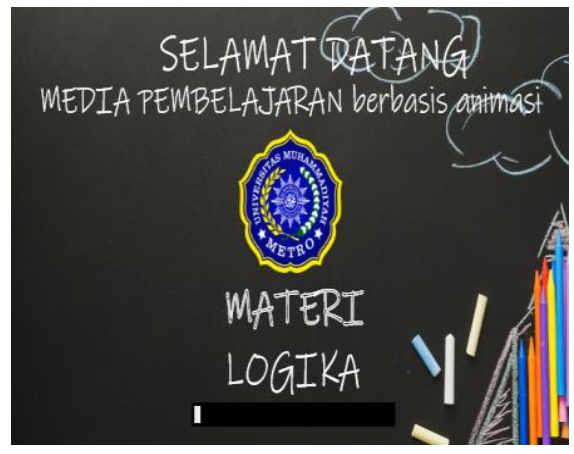

Figure 2. Display Intro.

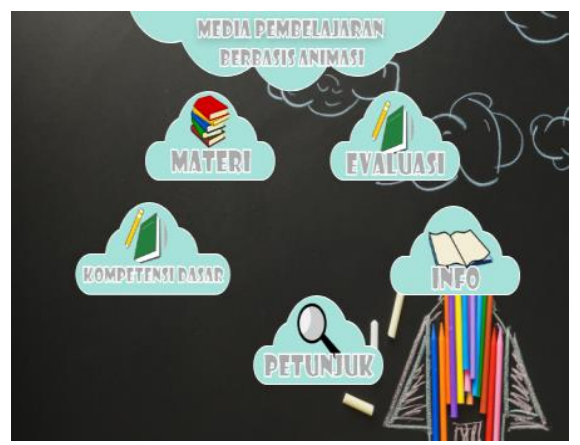

Figure 3. Main Display.

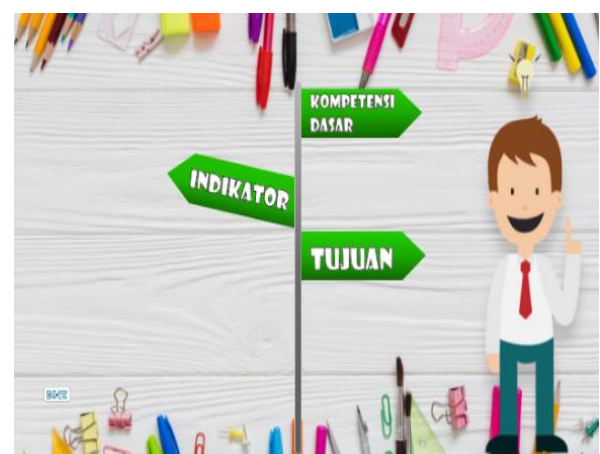

Figure 4. Display KD, Indicators and Objectives.

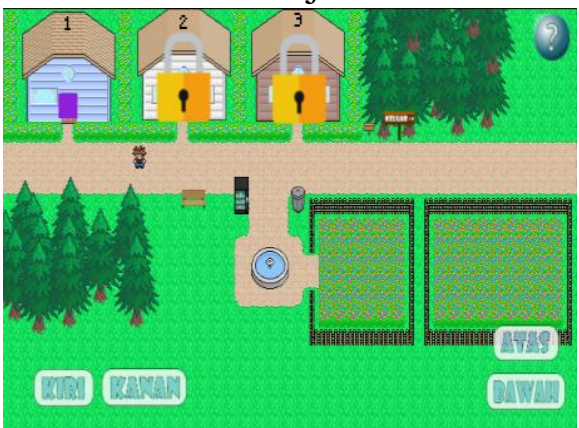

Figure 5. Material House

Figure 2. An intro display of an animation-based learning media application that has been designed / design. Figure 3. Contains the main menu display which contains the Material, Evaluation, Developer Info, Usage Instructions and Basic Competency menus. Figure 4. Contains the appearance of the Basic Competence, Indicator and Purpose menu in accordance with the K13 book used in the development of animation-based media. Figure 5. Contains logic material in each house as shown in the above display and there are problems in it.

\section{Expert Validation Results}

The data was obtained from the results of the validation carried out by 6 validators, namely 3 material experts (MA) and 3 media experts (ME) consisting of 3 Lecturers of the University of Muhammadiyah Metro and 2 Teachers from SMA 1 Purbolinggo.

The validator research data by the material expert towards the animationbased learning media on the logic material of SMA Negeri 1 Purbolinggo grade XI, the average percentage is presented as follows: 
Table 3. Average Percentage of Eligibility for Animation Media

\begin{tabular}{ccc} 
Validator & Average Percentage & Categories \\
\hline V1 MA, V2 MA, \& V3 MA & $89 \%$ & Very decent \\
\hline V4 ME, V5 ME, \& V6 ME & $90 \%$ & Very decent \\
\hline Average & $90 \%$ & Very decent \\
\hline
\end{tabular}

Hasil penilaian dari keenam validator ahli yaitu 3 ahli materi dan 3 ahli media terhadap media pembelajaran secara umum sudah baik tetapi perlu ada revisi. Setelah dilakukan revisi dari masing-masing komentar validator, maka media tersebut diajukan kembali untuk persetujuan kevalidasinya kemudian akan diuji cobakan.

\section{Small Group Trial Results}

The results of the trial in a small group of 10 students in the form of comments and suggestions. Student questionnaire response data on animation-based learning media on class XI logic material is presented as follows:

Table 4. Student Questionnaire Response Data in Small Group Trials

\begin{tabular}{cccc}
\hline Students & Score & Average $(\%)$ & Categories \\
\hline 1 & 68 & $91 \%$ & Very practical \\
\hline 2 & 75 & $100 \%$ & Very practical \\
\hline 3 & 69 & $92 \%$ & Very practical \\
\hline 4 & 71 & $95 \%$ & Very practical \\
\hline 5 & 67 & $89,3 \%$ & Very practical \\
\hline 6 & 67 & $89,3 \%$ & Very practical \\
\hline 7 & 72 & $96 \%$ & Very practical \\
\hline 8 & 59 & $79 \%$ & Practical \\
\hline 9 & 60 & $80 \%$ & Practical \\
\hline 10 & 70 & $93,3 \%$ & Very practical \\
\hline Total & 678 & $90,49 \%$ & Very practical \\
\hline
\end{tabular}

The data in Table 4. above is the assessment of students about learning media. Students who have filled in the response questionnaire by containing the items that have been listed on the questionnaire and assigning grades to the average percentage category are very practical. 


\section{CONCLUSION AND RECOMMENDATIONS}

Animation-based learning media using construct 2 are declared valid and practical so that it can facilitate students in the learning process both within the scope of the school and at home. In addition, this animation-based learning media can facilitate students to learn independently and repeatedly to understand the material being studied. Animation-based learning media has the following advantages and disadvantages:

Advantages:

a. As one source of independent learning of students on logic material.

b. Make students interested in learning.

c. Animation-based learning media is increasingly interesting.

d. Media is easy to use and can be learned anywhere and anytime.

e. Media can motivate students in learning to be more enthusiastic.

Deficiency:

a. The study did not use methods or learning strategies.

b. Limited to logic material.

c. Evaluation questions are only multiple choice, not essay

This research still has some shortcomings. Further research is still very open to be done. One of them is the development of media in other materials.

\section{REFERENCES}

Barus, Ulian \& Suratno. (2015). Pemanfaatan Candi Bahal Sebagai Media Pembelajaran Alam Terbuka Dalam Proses Belajar Mengajar. Medan: Perdana Mitra Handalan.

Iis, E. \& Totok, S. (2017). Uji Kelayakan Media Pembelajaran Interaktif pada Mata Pelajaran Administrasi Server. Jurnal Elinvo Vol 2/No 2. Yogyakarta: UNY.

Jalinus, N. \& Ambivar. (2016). Media dan Sumber Pembelajaran. Jakarta: Kencana.

Nieveen, N. (2007). Formative Evaluation in Educational Design Research. Dalam Plomp T \& Nieeven, N (Eds). An Intruction to Educational. Netherland: SLO. 
Pietono. (2014). Mendidik Anak Sepenuh Hati. Jakarta: PT Elex Media Kompotindo Kelompok Gramedia.

Riduwan \& Akdon. (2013). Rumus Data dalam Aplikasi Statistika. Bandung: Kencana.

Shodikin, A. (2017). Pengembangan Bahan Ajar Kalkulus Integral Berbasis Animasi. Jurnal Aksioma Vol.6/No.1.

Sudaryono. (2013). Pengembangan Instrumen Penelitian Pendidikan. Yogyakarta: Graha Ilmu.

Sutarti, T., \& Edi I. (2017). Kiat Sukses Meraih Hibah Penelitian Pengembangan. Yogyakarta: CV Budi Utama. 